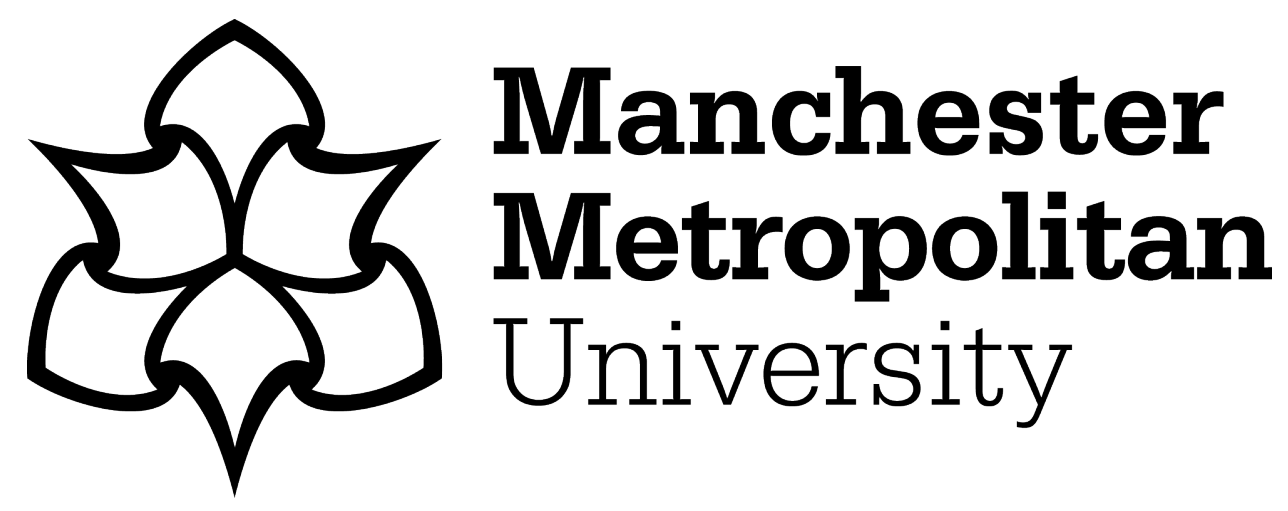

Binnie, Jonathan and Klesse, Christian (2018) Comparative queer methodologies and queer film festival research. Studies in European Cinema, 15 (1). pp. 55-71. ISSN 1741-1548

Downloaded from: https://e-space.mmu.ac.uk/620303/

Version: Accepted Version

Publisher: Taylor \& Francis (Routledge)

DOI: https://doi.org/10.1080/17411548.2018.1434364

Please cite the published version 


\section{Comparative Queer Methodologies and Queer Film Festival Research}

\section{Introduction}

In this paper, we wish to explore how a focus on the queer politics of comparison can contribute towards research on queer film festivals. Our discussion of comparison draws on a qualitative research project, which examined five queer film festivals in six different European cultural geopolitical contexts as sites for the production of visibility, solidarity and queer space, as well as motors for the reproduction of networks around film production, political and educational interventions. We argue that a queer comparative methodological approach to queer film festivals is wary of the pitfalls of universalism and essentialism regarding gender and sexual subjectivity, political strategy and spatial imaginary. We suggest that queer analysis needs to be attentive to postcolonial critiques if it wishes to challenge hegemonic notions of temporality that result in a stratified representations of European space. Both comparison and cultural translation need to be informed by a positionality-focused approach that highlights partiality, geopolitical contexts and cultural distinctiveness while aiming at a transversal hermeneutics that decentres taken-for-granted assumptions about subjectivity, culture, place and politics.

In the discussion that follows, we will review wider debates on comparative methodologies in urban, feminist, postcolonial and queer studies in order to sketch a model of queer comparison that is informed by relational, regional 
and postcolonia/ perspectives. We will then present a brief discussion how the questions of relationality, cultural dynamics within regions and problematic notions of spatialised temporality have played out in our own comparative study of five queer film festivals in Europe. We then progress to argue, drawing on debates in cultural studies and (queer) translation studies, that queer practices of comparison are dependent on a method of cultural translation informed by critical hermeneutics, self-reflexivity, analysis of geopolitical hegemonies and a sense of partiality cum transversality. In the conclusion, we synthesise the arguments presented in the respective sections of the paper to stress that queer comparison is consistant with a process aimed at 'transversal understanding' (Guttiérrez Rodríguez 2006) rather than an 'objective science'. We believe that these conceptual and methodological insights are conducive to the development of methodological approaches to the study of queer film festivals because the pitfalls and potentials of comparison are key to the understanding of such festivals as networked phenomena (Elsaesser 2005; De Valck 2007, De Valck et al. 2016).

\section{Towards a relational comparative methodology in queer film festival} research

Comparative methodologies have recently been met with critical reappraisals within a number of disciplines, including urban, feminist, queer and postcolonial studies. For example, within urban studies Ward has argued for a 
relational mode of urban comparison that seeks to overcome the essentialising tendencies of more conventional comparative urban research that focuses on absolute differences between cities, rather than on any flows or connections between them. Instead, Ward advances a relational approach to comparison that seeks to understand the relations - the interconnections between cities in terms of policy-making, but also how cities can be implicated in the pasts, presents and futures of politics in other cities. Ward's (2010) approach to comparison helps us to ask how experiences and conditions in one urban context can be used productively to ask questions about and inform urban politics in other cities. In a similar vein, Robinson (2011) has argued that a renewed interest on comparative urbanism is necessary to produce a more cosmopolitan urban studies. For Robinson, comparison is a chief tool of urban studies that derives its significance from the networked condition of contemporary urban space: 'The very fact that cities exist in a world of other cities means that any attempt at a general or theoretical statement about cities either depends upon or invites comparative reflection' (Robinson 2011: 1). At the same time, Robinson's call for a reinvigorated interest in comparative urbanism is inspired by a desire to challenge the way in which urban theory has been parochial in its focus on Western cities and neglect of cities outside the West.

Beyond urban studies - in transnational feminist studies, too - there has been a renewed interested in the politics of comparison. For example, Pedwell (2010: 1) has argued that: 'cross-cultural comparison has become central to 
debates on gender and cultural difference'. Pedwell's work is concerned with issues of particularity and connection within feminist debates on cross-cultural comparison. She asks what is at stake when comparisons are mobilised what are the rhetorical and material effects of comparison? Here she is in particular interested in questions of universalism and essentialism within comparative methodologies. From a queer theory perspective, O'Rourke (2011:xv) has suggested that: 'queer is a term that changes its register, meaning and operation from one locality to another'. This statement signals an affinity between queer and the comparative. Queer is a term coined to epitomise difference, ambiguity, and significatory excess (in particular in counter-normative settings), has been notoriously difficult to pin down since its inception (McKee 1999). The meanings attached to queer can change as it travels across different cultural and political terrains (Mesquita, Wiedlack and Lasthofer 2012). For example, Mizielińska and Kulpa (2011) highlight the cultural relativism of the term 'queer' and show that queer signifies a different set of assumptions, theoretical dispositions and policy orientations in Poland and other Central and Eastern European countries as Anglo-Saxon contexts (see also Mizielińska 2011, Szulc 2011). This has consequences for how researchers may approach a comparative study of queer film festivals, as what we mean and understand by queer is dynamic and shifting and changing between the different festival locations.

Moisio (et al. 2014) have called for the need to focus on matters of popular culture beyond merely institutional processes in order achieve contextually 
grounded interpretations of Europeanisation. A comparative study of multiple festivals thus allows researchers to explore 'context-specific geopolitical imaginations' (Moisio et al, 2014: 753), which are produced at and through queer film festivals in different contexts across Europe. Tascón (2015) argues that while many film festivals screen films from all over the world, many continue to mobilise a large percentage of their audience from within the locality. Tascón thus reminds us of the necessity to study film festivals as a locally embedded phenomenon. A similar insight can be drawn from Stringer's (2008) argument that even festivals that aim to generate 'specialist' audiences around 'minority tastes' or 'minority experiences' engage in marketing strategies that appeal to 'everyone', i.e. that construe the whole city population as a potential audience. The significance of film festivals for local economies, for example, the tourist industry has also been highlighted by many festival researchers (De Valck 2007, see also Burgess and Kredell 2016).

So far we have argued that although queer film festivals may consider themselves as part of a wider global or international network or 'circuit' of festivals their kind, each festival has to be understood in the context of its specific location. This 'locatedness' (within overlapping urban, regional, national and transnational dynamics) invites comparative strategies within research on queer film festivals. Yet we need to approach comparison with caution. Feminist and queer postcolonial scholars have drawn critical attention to the politics of comparison in transnational gender and sexual studies 
(Boellstorff, 2007; Spurlin, 2000). For instance, postcolonial queer studies have critiqued perspectives that seek to study and measure non-metropolitan, non-Western sexualities from supposed universal norms of Western 'gay' and 'lesbian' identity (Blackwood, 2008, Butler2008, Puar 2007, Haritaworn 2015). In different Central and Eastern European contexts, postcolonial critiques of Orientalism have been productively applied to sexual politics. For instance, Fejes and Balogh (2013: 4) criticise Western commentaries on LGBTQ activism and social movement politics in 'postsocialist' societies for lacking a nuanced and accurate analysis by alleging a match of geographical differences with a divide of cultural values, a strategy that culminates in the representation of a Western civilisational superiority over the East with regard to the scale of hypothesised acceptance of its LGBT population.

Postcolonial queer critiques both in Central and Eastern and Southern Europe have both challenged hegemonic discourses of sexual politics as 'backward' or 'less developed', in relation to North West Europe (see Boatcă, Costa, and Gutierrez Rodriguez 2010, Colpani and Habed 2014). Postcolonial critiques demonstrate that comparison is a difficult terrain. Conventional and common sense comparative reasoning sustains long histories of racist reasoning and sentiment within Europe and is a key operative logic within occidentalist forms of LGBTQ chauvinisms that are often discussed under the label 'homonationalism' (see Puar 2007, Haritaworn 2015). Careful and thorough study of context offers one way of escaping cultural essentialism. These postcolonial, queer critiques of comparison are particularly salient from any 
comparative study of sexual politics concerning sites located in different regions within Europe; and in the next section we will discuss how we addressed these critiques in our project. We also discuss some of the pragmatic challenges of comparative multi-site studies and provides conceptual mapping for systematic comparison of key contextual features of queer film festivals.

\section{Comparison and context}

Boellstorff (2007: 183) has suggested that: 'there is no such thing as pure comparison; comparison, like all knowledge, is in some way situated'.

Boellstorff's observation requires us to think through the relationship between comparison and context, and how we might conceptualise the latter. One of the major difficulties we faced is how to do theorise context and situation for context itself cannot be simply equated with place as a bounded territorial entity - particularly when it comes to studying festivals which take place in more than one locality. We therefore suggest that it is desirable to approach context in a relational sense - to examine the ways in which queer film festivals are connected to multiple localities and how they are placed within the wider sub-circuit of LGBT/Q film festivals (Loist 2016). There are examples of queer film festival research that uses a comparative approach. For instance, in their analysis of queer film festivals and their relationship to the global politics of queer cinema, Schoonover and Galt (2016) provide a 
comparative analysis of three film festivals - the MIX Queer Experimental Queer Film Festival in New York City, the KASHISH Mumbai International Queer Film Festival, and the Batho Ba Lorato Film Festival in Gaborone, Botswana. By considering these festivals together, Schoonover and Galt (2016: 86) state that: 'in concert, these festivals enable a more ambivalent accounting of transnational queer publics and of what it means to ask people to participate in cinema.' Central to their aim to capture the nuances of the transnational queer publics produced through these events, is their focus on the audience of these festivals, by which they envision as 'a set of material practices through queer publics are imagined, anticipated, and activated. These analyses offer contrasting modes of being public and very different scales of queer collectivity' (ibid., 86-87). In their analysis of the three festivals, they characterise the spaces of the MIX NYC festival as constituting spaces of an outsider oppositional queer utopianism, that they 'associate with a minoritizing politics' (ibid, 87). They contrast this with KASHISH in Mumbai, which, they argue 'work[s] from a universalizing premise' in seeking to appeal to queer and mainstream audiences and the mainstream Mumbai film industry. In their comparison of these three film festivals, the Batho Ba Lorato Film Festival sits in between the minoritising and universalising tendencies and character of these festivals: 'In programming and social media presence boldly addresses an LGBT community in Botswana while simultaneously connecting to transnational struggles for racial equality and social justice.' (ibid, 87). Summarising their framing of their approach to comparative 
analysis of these festivals, Schoonover and Galt, (2016: 87) argue that: 'Taken together, these festivals refute standard accounts of LGBT global politics. They demand that we pay much closer attention to how queers around the world create new venues for cultural expression and, indeed, alter the material terms in which queer life can be lived.' (ibid., 87). Reflecting on the way in which Schoonover and Galt (2016) approach comparison, we can see how it can add depth to an analysis - to recognise a heterogeneity of ways of doing queer film festivals i.e. the material practices of producing such event spaces and how they differ significantly from geopolitical location to location. In this sense, a comparative approach can add depth and nuance to the analysis of queer film festivals, and construct theoretical explanation based on widely differing queer geopolitical contexts.

\section{About the project}

In this section, we outline the rationale for our approach to comparison within our project on Queer Film Festivals as Activism. The film festivals we chose to study were the Sicilia Queer Film Festival in Palermo; the GAZE International LGBT Film Festival in Dublin; the Lesbisch Schwule Filmtage/International Queer Film Festival in Hamburg; the Mezipatra Queer Film Festival in Prague and Brno in the Czech Republic, and the Merlinka International Queer Film Festival in Belgrade. The project addressed the networked and relational spaces of solidarity, affinity and connection that shaped the production of 
these festivals, and their role in shaping public debates around LGBTQ politics and visibilities in each locality.

Building on our existing work on event-based solidarities and LGBTQ activism in Central and Eastern Europe (Binnie and Klesse 2011a; 2011b; 2012; 2013a, 2013b), we sought to develop our understanding of the role of queer cultural festivals as key spaces of activism - particularly as in the Polish context, and in a number of other political contexts in Central and Eastern Europe, it was the contested and sometimes violent nature of LGBTQ pride and equality marches that had received the most attention from activists and academics rather than the cultural festivals often connected with them. Eleftheriadis (2014: 152) has suggested that: 'queer festivals function as transnational arenas, and that they develop an alternative form of Europeanness-that is, a 'counter' Europeanness that attempts to create new forms of transnational solidarities.' At the same time, it is important to recognise that such festivals may also reproduce exclusions around race and class (Andreassen and Ahmed-Andresen, 2014); and such forms of 'counter" Europeanness' described by Eleftheriadis may themselves also be entangled within hegemonic geo-temporal framings of Europe as a site of sexual modernity and progress.

We were therefore drawn to exploring the transnational dimensions of queer film festivals as a site of transnational encounters, exchanges and networking (see de Valck 2016). At the same time, we are interested in capturing the 
distinctive nature of these events shaped by local and regional concerns and cultural dynamics. This interest sustains a multi-disciplinary approach to the field that draws upon debates beyond film studies within sociology, human geography, urban studies, European studies and postcolonial studies. Aiming to capture the ambiguous nature of queer film festivals as events that take place at the same time in local and transnational space, invites a queer method of comparison.

Burgess and Kredell (2016) suggest that film festivals can be studied in manifold ways and that (repeated) participation is not necessarily the only and chief method for successfully doing research into specific film festivals. We opted for a mixed-method approach involving participant observation, interviews with selected core participants and documentary research (regarding media coverage, press releases, web pages, programme guides, posters, trailers, merchandise (such as books, magazines, T-shirts, coffee mugs, buttons, etc.) and other ephemera) (Zielinski 2016). The combination of these methods allows for capturing the size and reach and distinctive flavour of the events in question (de Valck 2016), key features of the 'festival image' (Stringer 2008), budget and funding regimes, modes of labour (Loist 2011), programming strategies (cinematic genres, programme structure, identity references, construction of audiences, topics and geographical focus (June 2004, Loist 2012), educational activities and political engagement (if any), debates and conflicts (if any), modes of formal and informal organising (in social, spatial, temporal, economic and legal terms) (Loist 2011), 
community focus (Rich 2006), groups of stakeholders (Burgess and Kredell 2016), relationships with other festivals and positions within relevant circuits (Loist 2016) and their economic underpinnings (Rhyne 2006) and the question to what extent the festivals are themselves engaged in film funding, production, distribution or marketing (Loist 2016). Yet concern with context has to go beyond the isolated event (or sequence of events). Queer film festivals are embedded in longer histories of gender and sexual politics, shaped by past LGBT struggles and the cultures of activism that have been forged in them and the political, legal and economic conjunctures of the particular moment (Loist and Zielinski 2012, Eleftheriadis 2014).

Film festivals are multi-layered events. 'A film festival comprises an exhibition space; an event; and an institution with links to civil society, cinema culture, the film industry, and other festivals', argues Diane Burgess (in Burgess and Kredell 2016: 161). They emerge around nuclei of cultural work and activism, shaped both by local contexts and histories and transnational processes and encounters.

Our methodological approach has been inspired by Gamson (1996) who used a mixture of participant observation, in-depth interviews with key festival organisers as well as archival research of written material produced about and within festival organisations in his study of the organizational politics of lesbian and gay film festivals in New York City. In contradistinction to Gamson, however, we did not have the opportunity to engage in longitudinal 
observation. In total, we conducted 67 in-depth semi-structured qualitative interviews in the period between June 2013 and August 2015- focusing on the organisation and funding of these festivals and on the goals, aspirations and reflections of these key participants. Most of the interviews were conducted in English, apart from a small number of German language interviews. On a conceptual level, we wanted to examine festivals in different cultural geopolitical contexts and in urban locations with differing relationship to the politics of Europe and Europeanisation, and the on-going European financial, economic and political crisis. We therefore chose to include and compare festivals in different regional contexts - Central, Southern and South Eastern Europe, as well as North West Europe. Kajinić (2016) uses a queer regional approach to examine the cultural geopolitics of the Festival of Lesbian and Gay Film in Ljubljana, in order to produce an analysis that challenges 'methodological nationalism', by examining the festival in regional contexts beyond Slovenia. Kajinić argues that promotion and proclamation of the festival's status as being the first lesbian and gay film festival in Europe, must be seen in the context of Slovenian institutions reorientation towards dominant notions of Europeanness and European identity, and a distancing from the post-Yugoslav space. Furthermore, a queer regional approach can help us be receptive to the regional contexts at both a supranational and subnational scale. We therefore suggest that a mode of comparison based on a queer regional approach may be productive in examining the cultural geopolitics of queer film festivals. 
Spivak (2009b: 609) has argued that '[comparison is] never a question of compare and contrast, but rather a matter of judging and choosing.' We chose festivals in different regional geopolitical contexts within Europe, because we sought to capture a wider range of transnational flows and connections, than simply focusing on one context alone. We sought to understand the 'context-specific geopolitical imaginations' (Moisio et al, 2014: 753) that shape the production of these festivals; but are also addressed by these festivals. By examining queer film festivals in different regional geopolitical contexts, we did not seek to reproduce a cultural essentialism about these regions, which is an inherent danger. In her exhaustive overview of historical research on sexual cultures within Europe, Herzog (2009) notes how scholars have sometimes deployed the idea of regional sexual culture for instance in the case of the Mediterranean (see also Colpani and Hebed, 2014 for critique of the notion of a Mediterranean homosexuality). In selecting festivals in different regional contexts, we do not see them as representative of queer film festivals within these regions.

Fejes and Balogh (2013: 4) have argued that:

Western political and activist commentaries on post-socialist gay and lesbian rights movements tend to collide geographical differences with differentiating cultural values, whereby a so-called civilizational scale between the East and the West is established characterized by varying degrees of development and progress. 
In line with Fejes and Balogh's critique, we sought to conduct research on two festivals in different locations within Central and Eastern Europe; in which they both play key roles with regard to questions of queer visibility in the public sphere - the Mezipatra Queer Film Festival in Prague and Brno in the Czech Republic; and the Merlinka International Queer Film Festival in Belgrade. Mezipatra's role in promoting queer visibility in the public sphere is significant as its origins can be traced back to 2000, which means that it long predates the first Pride event in Brno in 2008, and Prague in 2011.

The Mezipatra International Queer Film Festival takes place in Prague and the second city of Brno in southern Moravia. There is also a regional touring programme of films from the festival in a number of Czech cities including Ostrava, Olomouc and Pilsen. The festival attracts around 11,000 visitors each year. It contains a comprehensive programme of discussions and social events such as parties. The festival is also used a platform for HIV/AIDS prevention work. The festival includes a short course on Transnational Film Studies and LGBTQ Cultures for students from George Washington University in Washington, D.C and the Charles University in Prague. The name Mezipatra means mezzanines in English - a spatial metaphor which encapsulates their approach to the event-space: 'Mezipatra (English translation mezzanines) is a space which is neither up, nor down. Whether you move upstairs or downstairs, you always meet your neighbours in the space which does not belong to either of the flats. Mezipatra (or mezzanines) have no specific owner, nor are there valid rules of entry of one and not the other. In the 
mezzanine, all the differences are irrelevant, no matter which floor you came from. Simply, you are and will always be welcome!' (Mezipatra, 2012). Mezipatra is organised by STUD Brno, which Nedbálková describes as 'the most influential gay and lesbian organization in the Czech Republic.' We decided to include Brno as well as Prague because Brno was the city where the festival originated in 2000 , and we wished to understand the role of the festival beyond the metropolis in a different regional context, in a smaller city, as so much critical attention has been devoted to queer film festivals in large metropolitan areas; reflecting the dominance of large metropolitan areas within historical and geographical research on sexualities more widely which has been a source of ongoing critique within the geographies of sexualities and beyond (Binnie, 2014; Brown, 2008; Myrdahl, 2013).

By examining and comparing Merlinka and Mezipatra, and bringing them into comparison with the other three festivals in our study, we can again challenge cultural essentialism around queer film festivals in post-socialist contexts. The Merlinka International Queer Film Festival in Belgrade is named after the transgender sex worker Vjeran Miladinović Merlinka, who was murdered in 2003. The festival was held for the first time in 2009. In 2013, the festival also included other cities in the region including Sarajevo in BosniaHerzegovina, and in Podgorica in Montenegro. Other public manifestations of queer visibility within Belgrade such as Pride marches have been highly contentious. Pride marches have been held intermittently in the city since the so-called 'Massacre Pride' of 2001 when 40 Pride participants were seriously 
injured by far right nationalists (Bilić, 2016). Organisers of Merlinka stressed that the festival had passed off peacefully, in marked contrast to the Pride marches which in recent years, either been banned, or only taken place with mass deployment of riot police (Bilić, 2016, Mikus, 2011). Unfortunately, in February 2014, a few months after we interviewed the festival director, Predrag Azdejković, he and two others were assaulted by masked attackers at the Sarajevo edition of the festival.

Colpani and Hebed (2014) have suggested that in order to best understand the relationship between Europeanisation, homonationalism and struggles for LGBT rights, we should attend to the southern and eastern peripheries of Europe (2014: 87). Colpani and Hebed argue that these peripheries are often absent from debates about homonationalism and European identity, but a critical focus on them may yield important insights about the relationship between homonationalism and Europeanisation. There are therefore sound conceptual reasons for choosing to study queer film festivals located in locations that hegemonic notions of European identity construct as peripheral i.e. outside of North West Europe.

Intriguingly, Colpani and Hebed state that: 'at this particular juncture, Italy occupies a position on the European map of liberal sexual politics similar to the position that Kuus (2004) ascribes to Central Europe in the context of the 2004 Europe's eastern enlargement' (Colpani and Hebed, 2014: 85). It is insightful that Colpani and Hebed relate their discussion of the southern 
periphery of Europe to the eastern periphery, and draw a comparison between the way these respective regions figure within hegemonic European geopolitical imaginaries. By including queer film festivals in Italy, the Czech Republic and Serbia, it was envisaged that we might be able to understand their interconnectedness within queer film and broader cultural networks and to ascertain networked transnational flows and connections beyond simplistic East-West and North-South dichotomies and trajectories. By focusing on a film festival in Italy, but also within the periphery of Italy; we also sought to question these dichotomies, as Italy, as Colpani and Hebed (2014) occupies a distinctive place within the idea of Europe; as not 'fully European' within dominant tropes of European sexual modernity and LGBT rights.

This is one of the reasons we chose to study the Sicilia Queer International Film Festival. This festival takes place in Palermo, and was founded after the first Pride march in the city in 2010. This upswing in activism occurred at a moment in shaped by anti-Mafia civil rights activism. Just as Italy can be seen to occupy a peripheral position to regard to hegemonic notions of European sexual modernity, Sicily occupies a peripheral position socially, economically, culturally and politically to the north of Italy. We have been sensitised to how our respondents frame their discussion of the contexts for their festivals in relation to these hegemonic discourses around 'progress' and 'backwardness' with regard to LGBTQ politics. For instance, a number of our respondents in Palermo sought to challenge hegemonic discourses of Sicily being 'backward' 
with regard to LGBTQ politics in both mainland Italy, and other parts of Europe, by drawing attention to the election of an out gay governor of the island in regional elections in 2012, Rosario Crocetto, a prominent anti-Mafia politician and the first left-wing governor of Sicily since 1947. Like other festivals in our project, Sicilia Queer was notable for a commitment to the promotion of film culture and education about gender and sexual politics and civil rights.

Sicilia Queer is distinctive for the ways in which it articulates a broad aesthetic vision of queer that goes beyond gender and sexual politics, to encompass disability for example. Compared to other festivals in our project, there appeared to be less of a concern with community-based representation. There is a strong commitment to educating audiences about film and civil rights. The festival, like others in our study, has been shaped by the urban cultural politics of its locality. In the editorial of the 2014 edition, the organisers state: 'we believe that a festival should look into an international scenario without ever forgetting its own territory. In our case, a deeply divided territory' (Sicilia Queer 2014, 4). At the same time, the international orientation of the festival was reflected in the inclusion of a number of films from the KASHISH Mumbai International Festival. Sicilia Queer is also a partner of the Iris Prize short film festival and competition, as were all the other festivals in our study apart from Merlinka. 
The decision to study the Hamburg festival was motivated by a desire to select a queer film festival in Northern and Western Europe - as a counter to the festivals in Southern, Central and Eastern Europe. The Hamburg festival had already been extensively studied, and there even existed an edited book about the history and development of the festival which was published to mark the $20^{\text {th }}$ anniversary of the festival (von Diepenbroick and Loist, 2009). The festival was already well-known to one of the authors as a major event in the Hamburg queer and alternative cultural scene. It is a grassroots community event based on collective principals with a strong basis in feminist and queer community organisation. This community ethic has been maintained despite the growth of the festival over its existence to being, according to the programme of the 2014 edition of the festival 'Germany's largest and oldest queer film festival (Lesbisch Schwule Filmtage, 2014, 8). It proclaims itself as community festival. In 2014, the festival was run by a team of 14 , plus a wider group of volunteers. The festival runs screenings across a number of venues in Hamburg. It also shares a commitment to wider questions of social justice and co-operates with left-wing/autonomous cultural institutions such as Rota Flora, a squatted social centre in the St. Pauli neighbourhood. The festival was selected because of its distinctive organisation structure, its commitment to broader goals of social justice, as well is its location in one of the most prosperous cities and regions in Germany. With its grassroots approach, the Lesbisch Schwule Filmtage/Hamburg International Queer Film Festival has developed within the 
context of the more left-wing politicized, anti-racist and queer-oriented sections of the wider LGBTQ political spectrum. Conceived within a more classical lesbian and gay identity-political framework, the festival decided to open up to the queer impulse of diversification by adding International Queer Film Festival to its original brand name. The decision to hold on to the previous name reflects both the wish by many in the group to preserve the legacy of this (political) history as well as it may represent a certain ambiguity with regard to the universalising effects of queer that also erase specificity (Woltersdorff, 2011).

The GAZE International LGBT Film Festival in Dublin is the final festival in our study. The festival celebrated its $25^{\text {th }}$ anniversary in 2017. Dublin was chosen among other reasons because we were interested in the relationship between Europeanisation and LGBT cultural politics. Austerity policies implemented as a result of the Eurozone crisis has had a disproportionate economic, social and political impact on Ireland (O'Flynn, Monaghan and Power, 2014) and we were concerned with how austerity affected the spaces of cultural activism associated with cultural institutions and festivals such as GAZE (see Binnie and Klesse (2018) for a more detailed discussion of the economic, cultural and political context of the GAZE festival). The human rights activism dimension of the festival was clearly evident, particularly in the 2015 edition of the festival which took place several months after the historic referendum on the Thirty-Fourth Amendment of the Constitution (Marriage Equality Bill) 2015 which saw same-sex marriage equality approved by $62 \%$ of voters. 
A focus on thinking comparison relationally also invites us to explore historical links and existing networks among the different festivals in our study. For example, in the early years of the Dublin festival, it had strong connections to the London Lesbian and Gay Film festival, and was originally in receipt of a touring package of films from this festival. Many of the festivals we studied contain close networks with other events both within and beyond the boundaries of national territories. For example, the organising team of the Lesbisch Schwule Filmtage/International Queer Film Festival in Hamburg were member of QueerScope, a network of Independent German Queer Film Festivals, which now organises thirteen different festivals (Queerscope 2016). The network allows smaller festivals that run in temporal proximity with each other to engage in joint negotiations about screening and transport fees and to coordinate the invitation of international guests to share costs for travel expenses (Loist 2014: 103fn). Individual respondents emphasised the existence of close links, among others, with Pride Pictures in Karlsruhe, Filmfest homochrom in Cologne and Dortmund, queerfilm festival, Bremen, Schwule Filmwoche, Freiburg and further with the Pink Apple Film festival in Zürich. Merlinka was notable for taking place across national borders in Sarajevo in Bosnia and Herzegovina and Podgorica in Montenegro as well as Belgrade.

In this section, we have outlined our rationale for the selection of film festivals in our study. We have also discussed how we mobilised a relational mode of queer comparison that draws on a queer regional approach to the 
study of cultural geopolitical context. The following section will address some of the epistemological questions bound up with cultural translation

\section{Queer comparison and cultural translation}

We have argued for an approach to comparison that takes account of the relational nature of queer film festivals and the mobile cultural work and activism around them. While being site-specific, queer film festivals take place within a transnational public sphere, which further takes recourse to a transnational (globalising) discourse of queerness. '"[Q]ueer is a term that brings problems of translation, transmission, transport and dissemination with it as it travels across borders', states O'Rourke (2011: xv). A number of writers have critically explored both the affinity between a queer paradigm and practices of translation and the need to look at queer politics from an angle of (cultural) translation (Baer and Kaindl 2017; Liinason and Kulpa, 2008; Mesquita, Widelack, and Lasthofer 2012). In this section, we outline a method of queer comparison as cultural translation that is attuned to power relations as they have been described in postcolonial scholarship. Comparison done in a queer spirit, we argue, hinges upon a sensitive approach towards 'cultural translation.'

Boellstorff (2007: 183) has argued that comparison is inherently queer, because it is a 'transcendent form of critique' that troubles 'established horizons of interchange'. At the same time, queer always seems to rest on a comparative approach, because it is 'an anti-foundational concept that seems 
to belong nowhere and this invites linkages across time and space' (ibid.: 183). Both comparison and a queer perspective therefore do not only invite but are profoundly dependent upon a sensitive approach towards difference, or - to put it in the words of Guttiérrez Rodríguez (2006) an approach to 'cultural translation' that aims at 'transversal understanding'. The concept of cultural translation has propelled fruitful debates in popular in anthropology and cultural studies. For example, Asad (1986) highlights the power dynamics of cultural translation as it has been practiced in the context of knowledge production within colonial anthropology. From a postmodern point of view, Bhabha $(1990,1994)$, too, focuses on power dynamics at the heart of cultural translation, while highlighting also the agency and potential subversive cultural politics of postcolonial diasporic subjects, who may create 'third spaces' through an epistemology of hybridity. In particular, Bhabha (1990) makes a point about the commensurability and inter-connectivity - and thus inherent translatability - of different 'cultures', because all cultures are symbol-forming practices.

Scholars from within translation studies have at times been somewhat wary of more generalised interpretations of cultural translation, because they fear that this would deflect from the art and skill of interlingual translation as a key element of cultural translation (Trivedi 2007). Spivak (2009a: 214), too, stresses the need of linguistic competence as a privileged - if not necessary road to cultural knowledge, understanding and solidarity. At the same time, she acknowledges (2009a: 200) that language is only one thing among others 
that we may draw upon to make sense of ourselves and the world around us, highlighting the significance of thinking, gesturing, silences and pauses. She thus places language into the context of lived and embodied communication. Beyond language competence, Spivak further points to the significance of geo-politics and cultural hegemony: 'The status of a language in the world is what one must consider when teasing out the politics of translation' (2009a: 214).' The hegemony of English and its role as lingua franca at many queer film festivals, thus poses a methodological problem. We agree with Baer (2017) that a stronger focus on language would benefit social scientific approaches to gender and transnational sexuality studies. We also think that it would have added strength to our own research, if we had the opportunity to conduct interviews with research participants in their native language (which was not possible at many of our research sites) or to watch films and engage with media surrounding the festivals in all the languages in which they have been produced. We certainly did have to take pragmatic decisions in the case of this research, also because of constraints in terms of funding and time. Yet we do believe that important insights can be gained from our multi-site comparative research, however partial such a contribution may be.

While we recognise the important role of interlingual translation in transnational festival research, we firmly believe that language is not the only medium through which to study queer film festivals. The multiplicity of visual worlds, social spaces, discursive publics, sensual registers, and intersubjective dynamics that make up film festivals is powerfully demonstrated in the 
contributions to De Valck, Kredell, and Loist's (2016) edited volume. This multiplicity appeals to multisensuality and ultimately invites a multiplicity of approaches, which calls into question the absolute primacy of purely linguistic or purely visual methods. Talking about film festival ephemera and archives of feeling, Zielienski (2016: 154) argues that 'festivals and festivality exceed their programming and are beyond the mere sum of their individual films'. In her paper on film festival ethnography Lee (2016: 130) suggests a very broad and multi-layered approach to the multiple 'textualities' of film festivals that by far exceeds a concern with the written word - or the spoken word for that matter.

We think Maitland (2017: 28) makes an important point when she considers cultural translation 'as the traceable presence of hermeneutic gestures of reading and writing in the construction and reception of a range of cultural phenomena present in the public sphere'. Maitland proposes a broader interpretation of cultural translation by fusing the model of intralingual translation with an ontological reading of Ricoeur's $(1996,2004)$ philosophical hermeneutics. Communication is here not the transmission of meaning but its creation in of dialogue and negotiation among embodied and contextualised actors. Such an integrated view, Maitland believes, avoids textual and cultural essentialisms by assuming that all interpretation is always contingent, an attempt at the creation of meaning in a world in which all symbols are polyvocal and not all communication is language based. Cultural translation as form of hermeneutic inquiry consists in a reflexive act of reaching outwards in 
awareness of the partiality and limits of one's own understanding and the risk of failure (Maitland 2017, 10).

In a similar vein, drawing heavily on postcolonial theory, Guttiérrez Rodríguez (2006) defines cultural translation as 'a process, in which ambivalent social and cultural positions are negotiated. Thus translation procures understanding at the same time that it points to the potentiality of un-translatability.' Cultural translation is concerned with transversal understanding (i.e. a mode of understanding that transcends rigid dichotomization of the self/other relationship) gives up the idea that translation is about recreating meaning in an act of perfect mirroring through a complete transfer of one act of symbolisation from within one semiotic code into another. Drawing on Benjamin (1923/2009), Guttiérrez Rodríguez suggests that to simply convey meaning would be a failure of translation: 'Translation as a process of incorporating the voice of difference into that of sameness destroys the potentiality of understanding the other voice in motion, inscribed in a movement of difference.' A similar reasoning can be identified in Spivak's (2009a) work on translation, in which she considers translation as a method of exploring the limits of one's own identity. 'True translation' in the sense of Benjamin's and Spivak's understanding of the term thus does not aim to copy the original 'text' or to fully capture and arrest the meaning inherent to the voices concerned. This allows Guttiérrez Rodríguez (2006) to construe translation 'as flux, as transitory movement', or as a never-ending process of communication (see Iveković 2006). A sound understanding of one's own and 
the research participants' social positioning is thus key to this approach to translation. This calls upon researchers to reflect upon their wider positioning within the field and the geo-political and socio-economic context shaped by capitalist accumulation and colonial histories (Guttiérrez Rodríguez 2006, 2008).

Queer film festivals produce very different spaces, socialities, and discourses in different locations of the world (Schoonover and Galt 2016). As a traveling concept the notion of queer itself has assumed very different meanings in different local and regional contexts (Baer 2017; Kulpa, Mizielińska, and Stasinska 2012; Mizielińska 2011). These insights suggest that both comparison and cultural translation are promising methodologies for queer film festival research. We have argued that both queer comparison and cultural translation are at best informed by a critical hermeneutics shaped by self-reflexivity and postcolonial analytics.

\section{Conclusion}

How is it possible to do comparison queerly when researching queer film festivals? A few conclusions can be drawn from our discussion of the critical ideas on comparison, context and cultural translation in relation to our own project on Queer Film Festivals as Activism.

Firstly, Ward (2010) has drawn critical attention to the politics of what he terms 'relational comparison' and has suggested that a renewed critical use of 
the comparative can make us aware of how experiences and conditions in one urban context can be used productively to ask questions about and inform urban politics in others. 'Relational comparison' acknowledges the importance of context and situationality, but deploys multiple and shifting frameworks to take account of multi-spatiality and the dynamics of networks and movements. Secondly, the use of a queer regional approach informed by postcolonial critiques of the region can contribute towards a comparative analysis of queer film festivals that challenges methodological nationalism and hegemonic ideas of European identity and Europeanisation. Thirdly, feminist and post-colonial scholars have directed our attention to the geopolitical discourses of temporality. Critical queer comparison thus needs to work against the discourses that deploy racialising imaginaries that fragment Europe into different time zones of gender and sexual politics. Fourthly, queer scholars have suggested an inherent affinity between the queer paradigm and comparison. We have argued that the 'queer potential' of comparison may be mobilised by a distinctive understanding of and approach to translation as a communicative process that is attentive to gaps, non-identity and the power function of dominant languages and conceptual registers. Again, postcolonial approaches that are attuned to the power/knowledge effects of spatial and temporal orderings in the wake of complex histories of geo-political domination are core to the development of a culturally sensitive approach to comparison. 


\section{References}

Andreassen, R. and U. Ahmed-Andresen. 2014. 'I can never be normal: a conversation about race, daily life practices, food and power.' European Journal of Women's Studies, 21(1): 24-42.

Asad, T. 1986. 'The concept of translation in British social anthropology'. In Writing culture: The poetics and ethics of ethnography, eds. J. Clifford and G.E. Marcu, 141-64. Berkeley, CA: University of California Press.

Baer, B.J. 2017. 'Beyond either/or: Confronting the fact of translation in global sexuality studies.' In Queering translation, translating the queer. theory, practice, activism, eds. B.J. Baer and K. Kaindl, 38-57. London: Routledge.

Baer, B.J. and K. Kaindl. 2017. 'Introduction: Queer(ing) translation.' In Queering translation, translating the queer. Theory, practice, activism, eds. BJ Baer and K Kaindl, 1-10. London: Routledge.

Benjamin, W. [1923] 2009. 'The task of the translator.' In One-way street and other writings, eds. W. Benjamin, 29-45. Harmondsworth: Penguin.

Bhabha, H.K. 1990. 'The third space.' In Identity, culture, difference, ed. J. Rutherford, 207-21. London: Lawrence and Wishart.

Bhabha, H.K. 1994. The location of culture. London: Routledge.

Bilić, B. 2016. 'Europe loves gays? Europeanisation and pride parades in Serbia.' In LGBT activism and Europeanisation in the post-Yugoslav space: On the rainbow way to Europe, ed. B. Bilić, 117-53. London: Palgrave Macmillan.

Binnie, J. 2014. 'Relational comparison, queer urbanism and worlding cities.' Geography Compass 8(8): 590-9.

Binnie, J. and Klesse, C. 2011a. "Because it was a bit like going to an adventure park': The politics of hospitality in transnational lesbian, gay, bisexual, transgender and queer activist networks.' Tourist Studies 11(2): 157-74.

Binnie, J. and Klesse, C. 2011b. 'Researching transnational activism around LGBTQ politics in central and eastern Europe: Activist solidarities and spatial imaginings.' In De-centring Western sexualities: Central and Eastern European perspectives, eds. R. Kulpa and J. Mizielinska, 107-29. Farnham: Ashgate.

Binnie, J. and Klesse, C. 2012. 'Solidarities and tensions: Feminism and transnational LGBTQ politics in Poland.' European Journal of Women's Studies 19(4):444-59.

Binnie, J. and Klesse, C. 2013a. 'The politics of age, temporality and intergenerationality in transnational lesbian, gay, bisexual, transgender and queer activist networks.' Sociology 47(3): 580-95. 
Binnie, J. and Klesse, C. 2013b. "Like a bomb in the gasoline station": EastWest migration and transnational activism around lesbian, gay, bisexual, transgender and queer politics in Poland.' Journal of Ethnic and Migration Studies 39(7): 1107-24.

Binnie, J. and Klesse, C. 2018. 'The politics of age and generation at the GAZE International LGBT Film Festival in Dublin.' The Sociological Review 66(1): 191-206.

Blackwood, E. 2008. 'Transnational discourse and circuits of queer knowledge in Indonesia.' GLQ: A Journal of Lesbian and Gay Studies 14 (4): 481-507.

Boatcă, M, S. Costa and Gutiérrez Rodríguez, E. 2010. 'Introduction: decolonizing European sociology: Different paths towards a pending project.' In Decolonizing Europe. Transdisciplinary approaches, eds. M. Boatcă, S. Costa, and E. Gutiérrez Rodríguez, 1-12. Aldershot: Ashgate.

Boellstorff, T. 2007. A coincidence of desires: Anthropology, queer studies, Indonesia. Durham, NC: Duke University Press.

Brown, G. 2008. 'Urban (homo)sexualities: Ordinary cities and ordinary sexualities.' Geography Compass 2(4): 1215-31.

Burgess, D. and B. Kredell. 2016. 'Positionality and film festival research: A conversation'. In Film festivals. History, theory, method, practice, eds. M. De Valck, B. Kredell and S. Loist, 159-76. London: Routledge.

Butler, J. 2008. 'Sexual politics, torture, and secular time.' British Journal of Sociology 59(1): 1-23.

Colpani, G. and A. J. Habed. 2014. 'In Europe it's different: Homonationalism and peripheral desires for Europe.' In: LGBT activism and the making of Europe: A rainbow Europe? eds. P. Ayoub and D. Paternotte, 233-40. Basingstoke: Palgrave Macmillan.

Elsaesser, T. 2005. 'Film festival networks. The new topographies of cinema in Europe.' In European cinema - face to face with Hollywood, eds. T. Elsaesser, 82-107. Amsterdam: Amsterdam University Press.

Eleftheriadis, K. 2014. 'Queer activism and the idea of 'Practicing Europe'. In: LGBT activism and the making of Europe: A rainbow Europe?'eds. P. Ayoub and D. Paternotte, 145-67. Basingstoke: Palgrave Macmillan.

Fejes, N. and A. Balogh. 2013. 'Introduction: Post-socialist politics of queer in/visibility.' In Queer visibility in post-socialist cultures, eds. N. Fejes and A. P. Balogh, 1-8. Bristol: Intellect.

Gamson, J. 1996. 'The organizational shaping of collective identity: The case of lesbian and gay film festivals in New York.' Sociological Forum, 11(2):23161.

Guttiérrez Rodríguez, E. 2006. 'Translating positionality: on post-colonial conjunctures and transversal understanding.' Transversal, Special Issue 'Under Translation', 06 2006, URL: 
http://eipcp.net/transversal/0606/gutierrez-rodriguez/en (last accessed: 14 August 2016).

Guttiérrez Rodríguez, E. 2008. 'Lost in translation - transcultural translation and decolonialisation of knowledge'. Transversal, Special Issue 'Borders, Nations, Translations', 06 2008, URL:

http://transversal.at/transversal/0608/gutierrez-rodriguez/en (last accessed 14 August 2016).

Haritaworn, J. 2015. Queer lovers and hateful others. Regenerating violent times and places. London: Pluto.

Iveković, R. 2006. 'On permanent translation. (We are being translated).' Transversal, Special Issue 'Under Translation', 06 2006, URL: http://transversal.at/transversal/0606/ivekovic/en (last accessed 3108 2016)

June, J. 2004. Defining queer: The criteria and selection process for programming queer film festivals. Queer Culture Work 8, 2, January 2004, URL: http://pages.uoregon.edu/culturwk/culturework26.html (last accessed 2008 2016).

Kulpa, R., Mizielińska, J. and A. Stasinska. 2012. '(Un)translatable queer? Or what is lost and can be found in translation'. In Import - export-transport. Queer theory, queer critique and activism in motion, eds. S Mesquita, M.K. Wiedlack, and K. Lasthofer, 115-164. Vienna: Zaglossus.

Lee, T. 2016. 'Being there, taking place: ethnography at the film festival.' In Film festivals. History, theory, method, practice, eds. M. De Valck, B. Kredell, and S. Loist, 122-137. London: Routledge

Liinason, M. and R. Kulpa eds. 2008. Queer Methodologies. (Special Issue) 5(2) 1-179.

Loist, S. 2011. 'Precarious cultural work: about the organization of (queer) film festivals.' Screen 52(2): 268-273.

Loist, S. 2012. 'A complicated queerness: LGBT film festivals and queer programming strategies.' In Coming soon to a festival near you: programming film festivals, ed. J. Ruoff, 157-72, St Andrews: St Andrews Film Books.

Loist, S. 2014. Queer film culture: Performative aspects of LGBT/Q film festivals. (Phd Thesis), Hamburg: Universität Hamburg, Institut für Medien und Kommunikation. URL: http://ediss.sub.unihamburg.de/volltexte/2015/7333/pdf/Dissertation.pdf (last accessed: 31 August 2016)

Loist, S. 2016. 'The film festival circuit: Networks, hierarchies, and circulation.' In Film festivals. History, theory, method, practice. eds. M. De Valck, B. Kredell and S. Loist, 49-64. London: Routledge.

Loist, S. and G. Zielinski. 2012. 'On the development of queer film festivals and their media activism.' In Film festival yearbook 4: Film festivals and 
activism, eds. D. Iordanova and L. Torchin, 49-62. St. Andrews: St. Andrews Film Books.

Maitland, S. 2017. What is cultural translation? London: Bloomsbury.

McKee, A. 1999. "Resistance is hopeless': Assimilating queer theory'. Social Semiotics 9(2): 235-249.

Mesquita, S., M.K. Wiedlack and K. Lasthofer (eds.) 2012. Import - export transport. Queer theory, queer critique and activism in motion. Vienna:

Zaglossus.

Mezipatra. 2012. Looking back at the first few years. http://ww.mezipatra.cz (Accessed January 8, 2018).

Mikus, M. 2011. 'State pride: Politics of LGBT rights and democratization in European Serbia.' East European Politics and Societies 25(4): 835-51.

Mizielińska, J. 2011. 'Travelling ideas, travelling times: on the temporalities of LGBT and queer politics in Poland and the "West". In De-centring Western sexualities: Central and eastern European perspectives, eds. R. Kulpa and J. Mizielińska, 85-107, Farnham: Ashgate.

Mizielińska, J. and R. Kulpa. 2011. 'Contemporary peripheries': Queer studies, circulation of knowledge and East/West divide. In De-centring western sexualities: Central and eastern European perspectives, eds. R. Kulpa and J. Mizielińska, 11-26. Farnham: Ashgate.

Moisio, S., Bachmann, V., Bialesiewicz, L., dell-Agnese, Dittmer, J. and V. Mamadouh. 2013. 'Mapping the political geographies of Europeanization.' Progress in Human Geography 37(6): 737-761.

Myrdahl, T. 2013. 'Ordinary (small) cities and LGBTQ lives.' ACME-An International E-Journal for Critical Geographies 12(2): 279-304.

Nedbálková, K. 2007. 'The changing space of gay and lesbian community in the Czech Republic'. In Beyond the pink curtain: Everyday life of LGBT people in Eastern Europe, eds. R. Kuhar and J. Takács, 57-71. Ljubljana: Peace Institute.

O'Flynn, M., L.Monaghan, and M.J.Power.2014. 'Scapegoating during the time of crisis: A critique of post-Celtic Tiger Ireland.' Sociology. 48(5): 921-37.

O' Rourke, M. 2011. "Europe': faltering project of infinite task? (Some other headings for queer theory).' In: Queer in Europe: contemporary case studies, eds. L. Downing and R. Gillett, xiii-xviii. Farnham: Ashgate.

Pedwell, C. 2010. Feminism, culture and embodied practice: the rhetorics of comparison. London: Routledge.

Puar, J. 2007. Terrorist assemblages: Homonationalism in queer times.

Durham, NC: Duke University Press.

QueerScope. 2016. Über/About QueerScope. http://queerscope.de/ueber (accessed August 14, 2016). 
Rhyne, R. 2006. 'The global economy of gay and lesbian film festivals.' GLQ: A Journal of Lesbian and Gay Studies 12(4): 617-19.

Rich, B.R. 2006. 'The new homosexual film festivals.' GLQ: A Journal of Lesbian and Gay Studies 12(4): 620-23.

Ricoeur, P 1996. 'Reflections for a new ethics of Europe.' In Paul Ricoeur: The hermeneutics of action, ed. E. Kearney, 3-14. London: Sage.

Robinson, J. 2011. 'Cities in a world of cities: The comparative gesture.' International of Urban and Regional Research 35(1)1-23.

Schoonover, K. and R. Galt. 2016. Queer cinema in the world. Durham, NC.: Duke University Press.

QueerScope (2016) 'Über | About QueerScope', URL:

http://queerscope.de/ueber (date of access: 14 August 2016)

Rhyne, R. (2006), 'The global economy of gay and lesbian film festivals', GLQ: A Journal of Lesbian and Gay Studies, 12(4): 617-619.

Rich, B.R. (2006), 'The new homosexual film festivals', GLQ: A Journal of Lesbian and gay Studies, 12(4): 620-623.

Ricoeur, P. (1996) 'Reflections for a new ethics of Europe', in E Kearney (ed.) Paul Ricoeur: The Hermeneutics of Action. London: Sage, 3-14

Ricoeur, P. (2004) The Conflict of Interpretations. London:

ContinuumRobinson, J. (2011) 'Cities in a world of cities: the comparative gesture.' International Journal of Urban and Regional Research 35 (1) 1-23.

Schoonover, K and Galt, R. (2016) Queer cinema in the world. Durham: Duke University Press.

Sicilia Queer. 2014. Sicilia Queer 2014 International LGBT and New Visions Filmfest. $4^{\text {th }}$ ed. Palermo: Sicilia Queer.

Spivak, G.C. 2008. 'More thoughts on cultural translation.' Transversal, Special Issue 'Borders, Nations, Translations', 06 2008, URL:

http://transversal.at/transversal/0608/spivak/en (last accessed 14 August 2016)

Spivak, G.C. 2009a. 'The politics of translation.' In Outside in the teaching machine, ed. G.C. Spivak, 200-25. London: Routledge.

Spivak, G. 2009b. 'Rethinking comparativism.' New Literary History, 40, no. 3: 609-626.

Spurlin, W. J. 2000. 'Remapping same-sex desire: queer writing and culture in the American heartland.' In: De-centring sexualities: politics and representations beyond the metropolis, eds. R. Phillips, D. Watt and D. Shuttleton, 182-198. London: Routledge.

Stringer, J. 2008. 'Genre films and festival communities: Lessons from Nottingham, 1991-2000.' Film Internationa/ 6, no. 4: 53-59. 
Szulc, L. 2011. 'Queer in Poland: under construction.' In: Queer in Europe:

Contemporary case studies. eds. L Downing and R Gillett, 159-172. Aldershot: Ashgate.

Tascón, S. 2015. Human rights film festivals: activism in context. Basingstoke: Palgrave Macmillan.

Trivedi, H. 2007. 'Translating culture vs. cultural translation.' In Translation: reflections, refractions, transformations, eds. P. St-Pierre and P.C. Kar, 27787. Amsterdam: John Benjamins Publishing.

De Valck, M. 2007. Film festivals: From European geopolitics to global cinephilia. Amsterdam: Amsterdam University Press.

De Valck, M. 2016. 'Introduction: What is a film festival? How to study film festivals and why you should?' In Film festivals. History, theory, method, practice, eds. M. De Valck, B. Kredell and S. Loist, 1-12. London: Routledge.

De Valck, M, Kredell, B and Loist, S. (eds.) 2016. Film festivals. History, theory, method, practice. London: Routledge.

Von Diepenbrock, D. and S. Loist. 2009. Bildschön: 20 jahre lesbisch schwule filmtage. Hamburg: Männerschwarm.

Ward, K. 2010. 'Towards a relational comparative approach to the study of cities.' Progress in Human Geography 34, no. 4. 471-487.

Woltersdorff, V. 2011. 'Paradoxes of precarious sexualities: Sexual subcultures under neo-liberalism.' Cultural Studies 25(2): 164-82.

Zielinski, G. 2016. 'On studying film festival ephemera. The case of queer film festivals and archives of feeling.' In Film festivals. History, theory, method, practice, eds. M. De Valck, B. Kredell and S. Loist, 138-58. London:

Routledge. 